\title{
Chemical and physical features of living and non-living maerl rhodoliths
}

\author{
Shane S. O'Reilly ${ }^{1}$, Sarah Hurley ${ }^{1}$, Nigel Coleman ${ }^{2}$, Xavier Monteys ${ }^{3}$, \\ Michal Szpak ${ }^{1}$, Tom O'Dwyer ${ }^{2}$, Brian P. Kelleher ${ }^{1, *}$ \\ ${ }^{1}$ School of Chemical Sciences, Dublin City University, Glasnevin, Dublin 9, Ireland \\ ${ }^{2}$ Chemical and Environmental Science Department, University of Limerick, Castletroy, Limerick, Ireland \\ ${ }^{3}$ Geological Survey of Ireland, Beggars Bush, Haddington Road, Dublin 4, Ireland
}

\begin{abstract}
Living (LM) and non-living maerl (NLM) rhodoliths of the species Lithothamnion corallioides (Crouan \& Crouan, 1867) from Kingstown Bay, Galway, were sampled and compared in relation to their physical structure and lipid and low molecular weight carbohydrate (LMWC) composition. Saturated (SATFA) and polyunsaturated fatty acids (PUFA) were dominant, in particular 16:0, 20:4n-6 and 20:5n-3, but a diverse range of fatty acids were identified. The abundance of $n$-alkanals was high, and sterol composition was simple, with cholesterol accounting for over $90 \%$ of the total sterols. Mono-, di-, and trisaccharides, with galactose units being dominant, and floridoside were present in high abundance. Notably, the fatty acid and LMWC profiles varied little between NLM and LM. The relatively high abundance of PUFA and floridoside, in particular, suggests that NLM may have further potential for research and commercial purposes in a variety of food, biomedical and industrial applications. Previously reported unidentified 'globular inclusions' were more abundant in NLM and exhibited a crystalline morphology. Together with the bacterial fatty acid composition of LM and NLM, the results indicate that these structures are not bacterial in nature.
\end{abstract}

KEY WORDS: Maerl $\cdot$ Coralline algae $\cdot$ Fatty acids $\cdot$ Floridoside $\cdot$ Lipids $\cdot$ Kingstown Bay $\cdot$ Galway Resale or republication not permitted without written consent of the publisher-

\section{INTRODUCTION}

Maerl is the collective name for a group of nongeniculate calcareous red algae (rhodoliths) from the family Corallinaceae, of which Phymatolithon calcareum (Pallas) (Adey \& McKibben 1970) and Lithothamnion corallioides (Crouan \& Crouan 1867) are the 2 primary maerl bed-forming species (Blunden et al. 1997, Foster 2001). Maerl beds occur globally (Bosence 1983, Freiwald \& Henrich 1994) and may be one of the world's 4 major marine benthic communities, along with kelp, seagrasses and nongeniculate corals (Foster 2001). Maerl beds are now known to function as spatially complex but sensitive habitats that support a rich and fragile biodiversity
(Barbera et al. 2003, Blake \& Maggs 2003, Bosence $\&$ Wilson 2003). The recent BIOMAERL project has shown that macroalgae, annelids, crustaceans and molluscs are particularly diverse in many maerl habitats (BIOMAERL Team 1999).

Living maerl (LM) is reddish-purple in colour and possesses abundant epiflora, while non-living maerl (NLM) is typically greyish-white to brown-white and lacks epiflora (Blunden et al. 1975). It is primarily NLM that is commercially exploited (Blunden et al. 1975) and has been collected off the Irish, Cornish and Brittany coasts since the 17th, 18th and 19th centuries respectively (De Grave \& Whitaker 1999). It is used as an agricultural fertiliser to increase the $\mathrm{pH}$ of acidic soils and also more recently for soil ameliora- 
tion, as an animal fodder additive, in acid water treatment, in biological denitrification, in drinking water treatment, in toxin elimination and in the pharmaceutical, cosmetics, nuclear and medical industries (Blunden et al. 1975, 1977, 1997).

The primary negative anthropogenic effects on maerl habitats are smothering with fine sediment from trawling and commercial exploitation (De Grave \& Whitaker 1998, Bordehore et al. 2003, Grall \& HallSpencer 2003, Wilson et al. 2004) and eutrophic conditions due to sewage and fish discharge (Wilson et al. 2004). The European Commission Council Directive 92/43/EEC, commonly known as the 'Habitats Directive', lists Lithothamnion corallioides and Phymatolithon calcareum in Annex $\mathrm{V}$ as being subject to management and conservation (European Council 1992). However, this only applies to Atlantic exploited maerl and not to any rarer species or non-commercially exploited maerl (Barbera et al. 2003). Data regarding the distribution of Irish maerl beds has been the topic of a recent report (De Grave \& Whitaker 1999), which concludes that 65 to $70 \%$ of all confirmed maerl beds in Irish waters occur in the Galway-Connemara region, 20 to $25 \%$ occur in the southwest region, and the remainder occur along the Donegal coast, with an overall abundance of the order of $3 \times 10^{6} \mathrm{~m}^{3}$ of exploitable maerl. With this vast resource, there has been renewed interest in maerl, both commercially and in terms of its ecological importance and conservation needs.

To date, the primary focus of research on maerl has been ecological and distribution studies (Barbera et al. 2003, and references therein). Previous studies have been carried out to characterise its physical and inorganic chemical composition (Borowitzka et al. 1974, Blunden et al. 1975, 1997), but there are few studies building on this work. Furthermore, coralline red algal deposits have been useful in paleoclimatic and paleoenvironmental reconstructions regarding global sea-level fluctuations (Titschack et al. 2008), seasonal climate variability (Freiwald \& Henrich 1994) and the use of the deposits as bi-weekly paleothermometers (Kamenos et al. 2008), but there have been no such applications using maerl deposits. To our knowledge, there has been no study of the biochemical composition of maerl and no comparison of the structural and compositional differences between LM and NLM to date. The purpose of the present study is to report on the solvent-extractable lipid and low molecular weight carbohydrate (LMWC) composition of LM and NLM from Kingstown Bay, Galway, Ireland, and to compare the physical and chemical composition of LM and NLM.

\section{MATERIALS AND METHODS}

\section{Sampling and sample preparation}

Dead and living maerl thalli were sampled using a benthic grab sampler in Kingstown Bay $\left(53^{\circ} 30.738^{\prime} \mathrm{N}\right.$, $10^{\circ} 6.486^{\prime} \mathrm{W}$ ) in 2009 (Fig. 1). Samples were stored at $4^{\circ} \mathrm{C}$ and a portion also at $-20^{\circ} \mathrm{C}$ prior to analysis. These samples were positively identified (AQUAFACT International Services) as Lithothamnion corallioides (Crouan \& Crouan, 1867). The samples were meticulously cleaned by physical removal of large flora, fauna and debris and the removal of adhered biomass and organic matter using tweezers and a small brush, followed by washing with deionised water. Sample aliquots were oven-dried at $110^{\circ} \mathrm{C}$ or lyophilised before grinding using a mortar and pestle and sieving through a $250 \mu \mathrm{m}$ sieve.

\section{Physical and chemical analysis}

Four representative thalli from LM and NLM samples were snapped according to Blunden et al. (1997) and adhered to carbon tabs. The samples were then sputter-coated with $\sim 30 \mathrm{~nm} \mathrm{Au}$ and imaged at $10 \mathrm{kV}$ accelerating voltage using a $\mathrm{HITACHI}^{\circledR}$ S-3000N scanning electron microscope. X-ray diffraction was performed on oven-dried $\left(110^{\circ} \mathrm{C}\right)$ powdered samples with a Philips ${ }^{\circledR} \mathrm{X}^{\prime}$ Pert X-ray diffractometer using $\mathrm{Cu} K \alpha$ radiation. The samples were measured in stepscan mode with steps of $0.04\left({ }^{\circ} 2 \theta\right)$ and a counting time of $1 \mathrm{~s}$. Infrared (IR) spectroscopy was performed using an Avatar 320 FT-IR spectrophotometer. Maerl samples were ground and mixed with $\mathrm{KBr}$ at an opti-

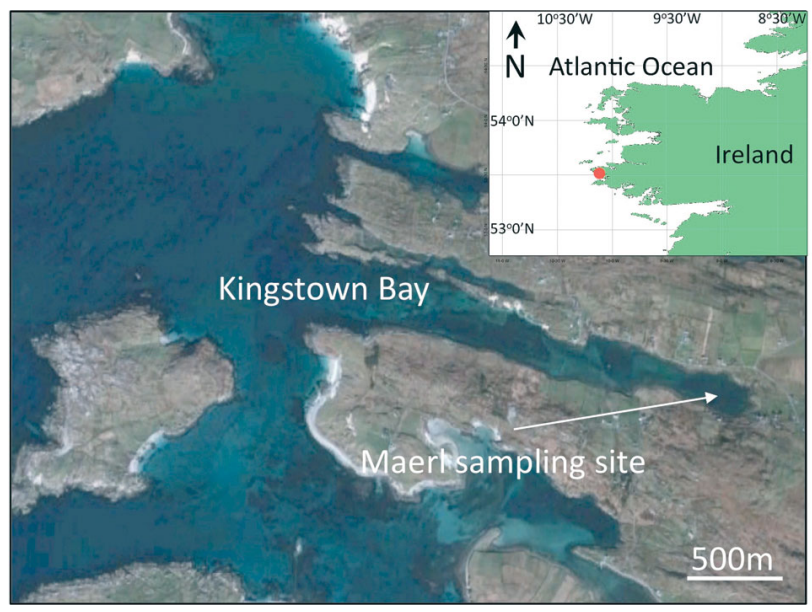

Fig. 1. Maerl sampling site, Kingstown Bay, Galway, Ireland (adapted from INFOMAR data and GOOGLE Earth ${ }^{\mathrm{TM}}$ ) 
mum ratio of 1:1000 (1 mg of sample in $1 \mathrm{~g}$ of $\mathrm{KBr}$ ), and a $\mathrm{KBr}$ pellet was prepared. Limestone was used as a comparison. Data was collected and processed using the EZ OMNIC (V6) operating software.

\section{Lipid and carbohydrate extraction}

All solvents (ROMIL-SpS ${ }^{\circledR}$ ), standards and reagents (Sigma Aldrich ${ }^{\circledR}$ ) were high-purity GC-grade. All glassware was heated for $8 \mathrm{~h}$ at $450^{\circ} \mathrm{C}$. Sub-samples of $2.5 \mathrm{~g}$ freeze-dried maerl were extracted by sequential ultrasonic-assisted extraction for $30 \mathrm{~min}$ each using the following solvent regime: $15 \mathrm{ml}$ $\mathrm{CH}_{3} \mathrm{OH}$, followed by $15 \mathrm{ml}$ 1:1 $\mathrm{CH}_{2} \mathrm{Cl}_{2}: \mathrm{CH}_{3} \mathrm{OH}$ and finally $15 \mathrm{ml} \mathrm{CH}_{2} \mathrm{Cl}_{2}$. Solvent extracts were combined, vacuum-filtered through furnace-treated glass fibre filters (Whatman ${ }^{\circledR} \mathrm{GF} / \mathrm{A}$ ) and reduced by rotary evaporation before being transferred to vials.

\section{Gas chromatography-mass spectrometry}

Total extracts were dried fully under $\mathrm{N}_{2}$ gas and reconstituted in 1:1 (v/v) $\mathrm{CH}_{2} \mathrm{Cl}_{2}: \mathrm{CH}_{3} \mathrm{OH}$. An aliquot was used to convert ester-linked lipids and free fatty acids to fatty acid methyl esters (FAMEs) using $0.5 \mathrm{M}$ sodium methoxide. A second aliquot of the total extract was used to silylate hydroxy-functional groups using 9:1 (v/v) N-O-Bis-(trimethylsilyl) trifluoroacetamide (BSTFA)/pyridine. Aliquots $(1 \mu \mathrm{l})$ of derivatised extracts were injected in splitless mode onto an Agilent ${ }^{\circledR} 6890 \mathrm{~N}$ gas chromatograph interfaced with an Agilent ${ }^{\circledR}$ 5975C mass selective detector (MSD). A HP-5MS fused silica capillary column $(30 \mathrm{~m} \times$ $0.25 \mathrm{~mm}$ i.d. and film thickness of $0.25 \mu \mathrm{m}$, Agilent ${ }^{\circledR}$ ) was used with high purity helium carrier gas at a constant $1.3 \mathrm{ml} \mathrm{min}^{-1}$ flow rate. The injector and mass spectrometer source were held at $280^{\circ} \mathrm{C}$ and $230^{\circ} \mathrm{C}$ respectively. The column temperature program was as follows: $65^{\circ} \mathrm{C}$ injection and hold for 2 min, ramp at $6^{\circ} \mathrm{C} \mathrm{min}^{-1}$ to $300^{\circ} \mathrm{C}$ followed by isothermal hold at $300^{\circ} \mathrm{C}$ for $20 \mathrm{~min}$. The mass spectrometer was operated in electron impact mode with an ionisation energy of $70 \mathrm{eV}$, with the mass scan range set from 50 to $650 \mathrm{Da}$.

Data was acquired and processed using Chemstation software (Version G1701EA). The monounsaturation position was identified on FAMEs by formation of DMDS adducts (Nichols et al. 1986), and all compounds were confirmed using a combination of NIST ${ }^{\circledR}$ and Wiley ${ }^{\circledR}$ mass spectral libraries, interpretation of mass fragmentation patterns and compound retention times and comparison with literature (e.g. Fang et al. 2006, Volkman 2006, Medeiros \& Simoneit 2007, Brokł et al. 2009). Analytes were quantified using total ion current peak area and converted to mass concentrations using multiple-point internal standard calibration curves. For each case, $100 \mu \mathrm{g} \mathrm{ml}^{-1} 5$ - $\alpha$ cholestane was used as an internal standard, and the analyte model compounds used were tetradecanoic acid methyl ester, D-(+)-glucose, nonadecane, stigmasterol and hexadecanol. Procedural blanks were run to monitor background interferences.

\section{RESULTS}

\section{Bulk physical and chemical composition}

X-ray diffractograms obtained from powdered LM (upper trace) and NLM (lower trace) are shown in Fig. 2. The peak $d$-spacing is consistent with calcite, and characteristic peaks for aragonite or dolomite were not apparent (Downs \& Hall-Wallace 2003). Fig. 3 shows representative IR spectra obtained from NLM, LM and limestone samples. Comparison with limestone highlights the distinct peaks attributable to carbonate, in particular the very strong peaks observed at $1420 \mathrm{~cm}^{-1}, 874 \mathrm{~cm}^{-1}$ and $718 \mathrm{~cm}^{-1}$ resulting from $\mathrm{C}-\mathrm{O}$ bonds. Peaks arising from organic functional groups are apparent in both LM and NLM but are minor. The peak and inverted peak at $2347 \mathrm{~cm}^{-1}$ in NLM and LM respectively is likely due to $\mathrm{CO}_{2}$ impurities.

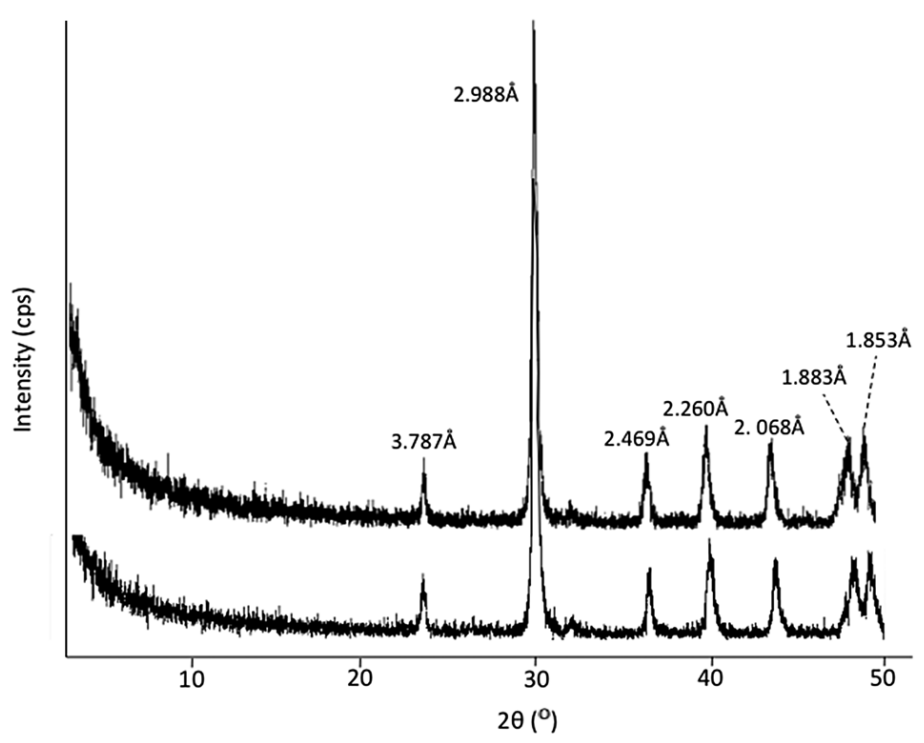

Fig. 2. Living (top) and non-living (bottom) maerl X-ray diffractograms. Peak $d$-spacings are labelled $(\AA)$ 


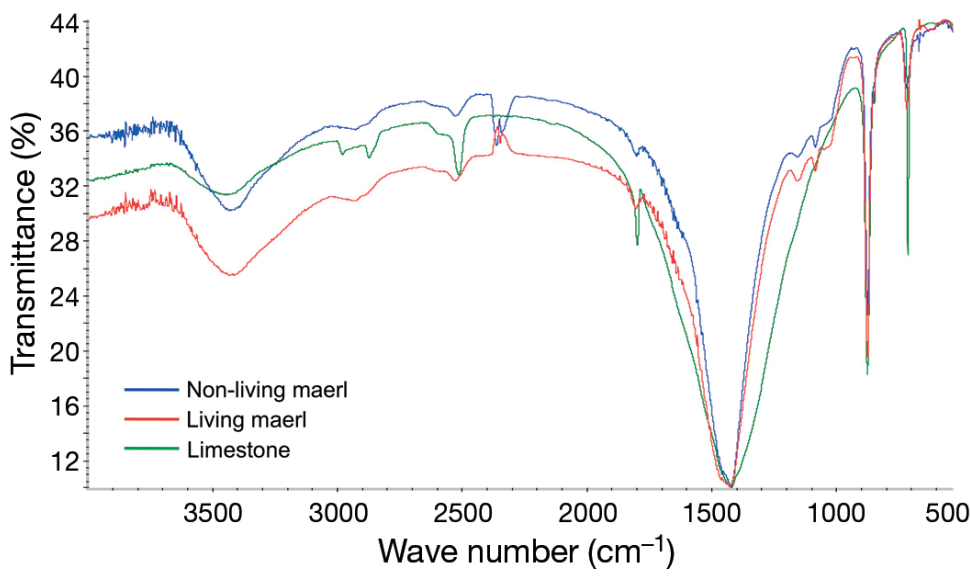

Fig. 3. Infrared spectra from non-living maerl, living maerl and limestone samples

\section{Scanning electron microscopy (SEM)}

The calcified structures of NLM and LM thalli were porous and contained globular inclusions (Fig. 4). These structures were significantly more abundant in the NLM than in the LM (Fig. 4). Fig. 5A shows SEM images of abundant globular inclusions (>2 $\mu \mathrm{m})$ with apparent angular morphology (Fig. 5A, ' $\mathrm{X}$ ') and also smaller $(<1 \mu \mathrm{m})$ cocci or streptococci-shaped structures (Fig. 5B, ' $\mathrm{Y}^{\prime}$ ).

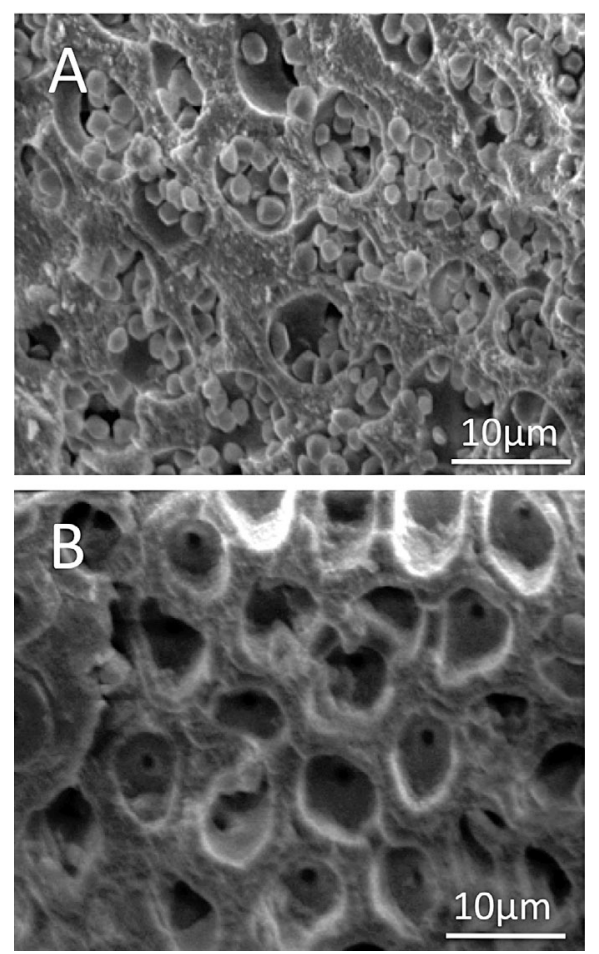

Fig. 4. SEM images of (A) non-living maerl, with abundant globular inclusions, and (B) living maerl, with notably fewer globular inclusions

\section{Fatty acid and simple lipid analysis}

A partial total ion chromatogram of saponified extract from LM is given in Fig. 6. FAMEs are labelled numerically according to standard nomenclature $X: Y \mathrm{n}-Z$, where $X$ is the number of carbon atoms in the chain, $Y$ is the number of double bonds present, and $Z$ is the position of the first double bond from the methyl end to the carbonyl end. Other compounds of interest are assigned alphabetically. The occurrence and abundance of fatty acids are given in Table 1. Among the saturated straight chain fatty acids (SATFA), 16:0 was the most abundant, accounting for $65 \%$ and $53 \%$ of the total SAFTA in LM and NLM respectively. SATFA ranged from $\mathrm{C}_{12}$ to $\mathrm{C}_{24}$ ' with an even-over-odd predominance. Monounsaturated fatty acids (MUFA) consisted of even-chain fatty acids ranging from $\mathrm{C}_{16}$ to $\mathrm{C}_{24}$. Unsaturation on the ninth carbon from the methyl end dominated, and $\mathrm{C}_{18}$ MUFA were the major form (48\% total MUFA), but there was also a relatively high abundance of 20:1n-9. MUFA were approximately twice as abundant in LM as in NLM. Polyunsaturated fatty acids (PUFA) were the second most abundant fatty acid class and primarily consisted of $\mathrm{C}_{20}$ PUFA (89\% of the total PUFA), with 20:4n-6 accounting for $49 \%$ of the total PUFA in LM. There was a greater abundance of PUFA in LM than in NLM. Small amounts of methyl-branched (including iso- and anteiso-) fatty acids were identified. Thus, the major fatty acids in LM and NLM were 16:0 (30.7 and $23.9 \%$ respectively), 20:4n-6 (14.3 and $15.6 \%$ ) and 20:5n-3 (6.9 and 8.6\%) (Table 1).

A range of other lipids was also identified in maerl (Table 2). The diterpene alcohol phytol $(3,7,11,15-$ tetramethyhexadec-2E-enol), which is the ester-linked side chain of chlorophyll $a$, and its degradation product phytanic acid $(3,7,11,15$-tetramethyhexadecanoic acid) were observed. The sterols cholesterol $(3 \beta-$ cholest-5-en-3-ol), $\beta$-sitosterol (Stigmast-5-en-3-ol) and stigmasterol (5,22-Stigmastadien-3 $\beta$-ol) were identified as the major sterol components of maerl, with cholesterol accounting for $89 \%$ of the total sterols in LM. Steroid or sterol biosynthetic precursors and metabolites were also identified, namely squalene $\quad(2,6,10,15,19,23$-hexamethyltetracosa-2, 6, 10, 14,18,22-hexaene) and cholest-4-en-3-one. The monoacylglycerols monopalmitin (2,3-dihydroxypropyl hexadecanoate) and monostearin (2,3-dihydroxypropyl octadecanoate) were found in significant amounts in LM and NLM (monostearin could not be quantified due to coelution with disaccharides). 

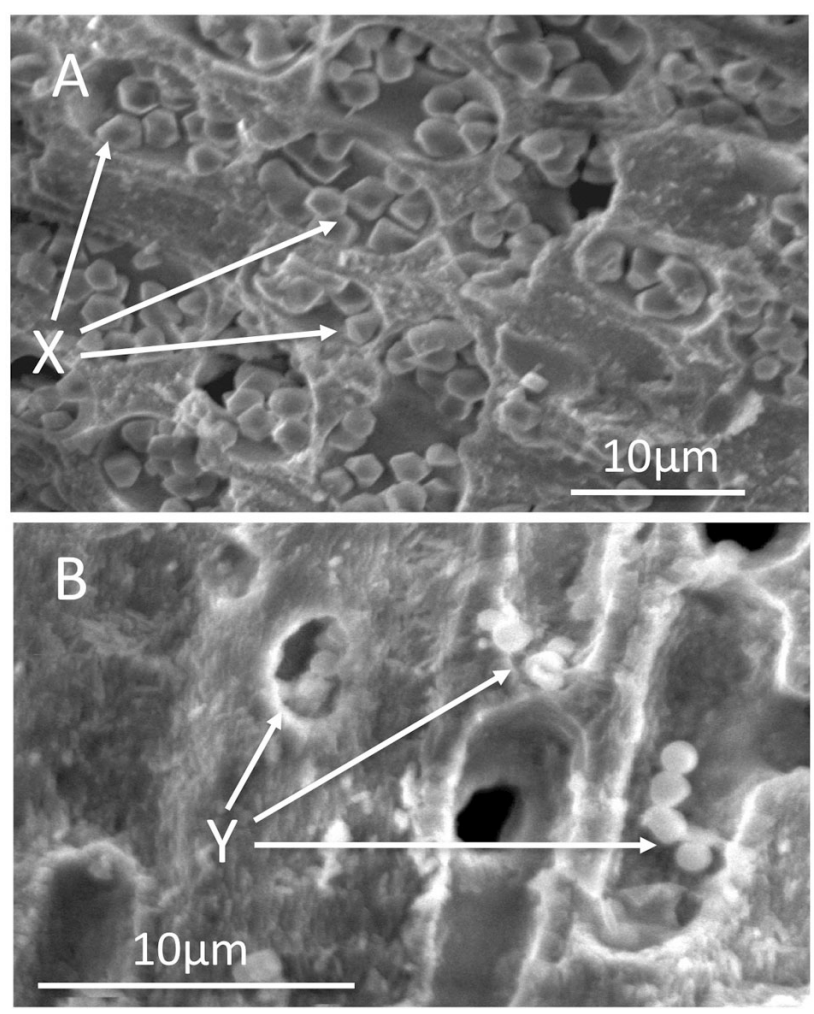

Fig. 5. SEM image of non-living maerl showing (A) globular inclusions with apparent angular morphology (X) and (B) $3.3 \mu \mathrm{m}$ pore structures and abundant bacterial $(\leq 1 \mu \mathrm{m})$ cocci- or streptococci-shaped structures $(\mathrm{Y})$

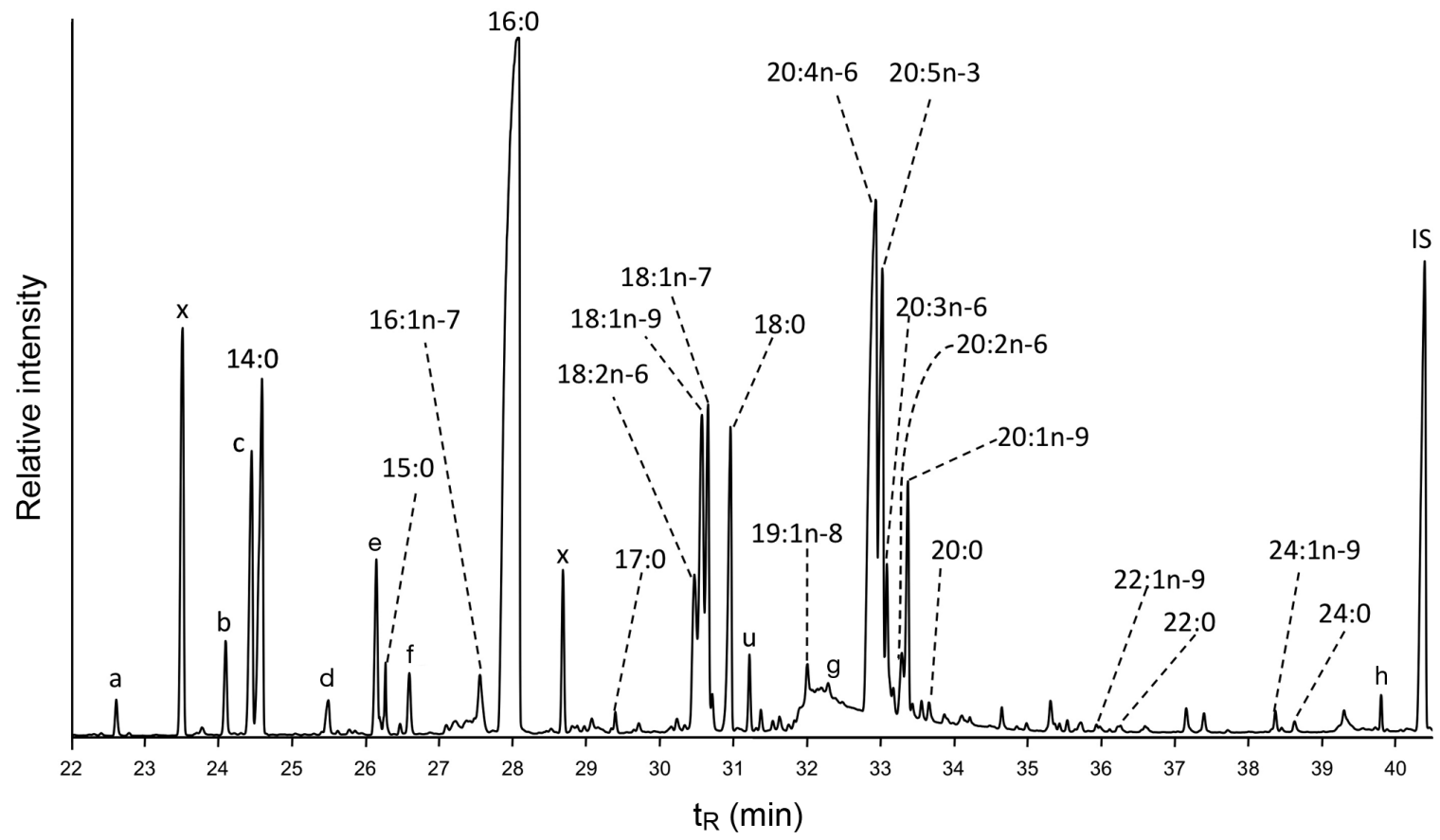

Fig. 6. Partial total ion chromatogram (TIC) of transesterified total extract from living maerl. Fatty acid methyl esters are numbered $X: Y n-Z$, where $X$ is the number of carbon atoms in the chain, $Y$ is the number of double bonds present, and $Z$ is the position of the first double bond from the methyl end to the carbonyl end. a: tetradecanal, b: heptadecane, $c_{i}$ hexadecanal, d: octadecanal, e: 6, 10, 14-trimethyl-2-pentadecanone, f: phytol, g: squalene, IS: internal standard, u: unknown, x: contaminant 
Table 1. Occurrence and concentration of fatty acids in living and non-living maerl. All fatty acids were identified as fatty acid methyl esters derivatives, and polar compounds were identified as trimethylsilyl-ether derivatives. MUFA double bond positions assigned by interpretation of DMDS adduct fragmentations (Nichols et al. 1986). SATFA: saturated fatty acids, MUFA: monounsaturated fatty acids, PUFA: polyunsaturated fatty acids, br-FA: branched fatty acids, DW: dry weight, nd: not detected, na: not applicable

\begin{tabular}{|c|c|c|c|c|c|c|c|}
\hline & \multicolumn{2}{|l|}{ Compound } & \multirow{2}{*}{$\begin{array}{l}\text { Molecular weight } \\
\quad\left(\mathrm{g} \mathrm{mol}^{-1}\right)\end{array}$} & \multicolumn{2}{|c|}{$\longrightarrow$ Living maerl -} & \multicolumn{2}{|c|}{ Non-living maerl -} \\
\hline & Common name & Number & & $\left(\mu \mathrm{g} \mathrm{g}^{-1} \mathrm{DW}\right)$ & $\%$ total fatty acid & $\left(\mu g g^{-1} \mathrm{DW}\right)$ & $\%$ total fatty acid \\
\hline \multirow[t]{13}{*}{ SATFA } & Lauric & $12: 0$ & 200 & 2.0 & 0.6 & 1.5 & 0.7 \\
\hline & Tridecanoic & $13: 0$ & 214 & 1.5 & 0.5 & 1.1 & 0.5 \\
\hline & Myristic & $14: 0$ & 228 & 20.1 & 6.0 & 11.8 & 5.5 \\
\hline & Pentadecanoic & $15: 0$ & 242 & 7.8 & 2.3 & 4.6 & 2.2 \\
\hline & Palmitic & $16: 0$ & 256 & 102.1 & 30.7 & 51.1 & 23.9 \\
\hline & Margaric & $17: 0$ & 270 & 3.3 & 1.0 & 2.1 & 1.0 \\
\hline & Stearic & $18: 0$ & 284 & 17.5 & 5.2 & 19.0 & 8.9 \\
\hline & Arachidic & $20: 0$ & 312 & 5.3 & 1.6 & 4.1 & 1.9 \\
\hline & Heneicosanoic & $21: 0$ & 326 & 1.3 & 0.4 & 1.3 & 0.6 \\
\hline & Behenic & $22: 0$ & 340 & 1.9 & 0.6 & 1.8 & 0.8 \\
\hline & Tricosanoic & $23: 0$ & 354 & 1.3 & 0.4 & 1.0 & 0.5 \\
\hline & Lignoceric & $24: 0$ & 368 & 1.8 & 0.5 & 1.6 & 0.8 \\
\hline & & Total & & 165.9 & & 101.0 & \\
\hline \multirow[t]{8}{*}{ MUFA } & Palmitoleic & $16: 1 \mathrm{n}-7$ & 254 & 8.3 & 2.5 & 4.1 & 1.9 \\
\hline & Vaccenic & $18: 1 n-7$ & 282 & 16.7 & 5.0 & 12.0 & 5.6 \\
\hline & Oleic & 18:1n-9 & 282 & 14.2 & 4.3 & 6.8 & 3.2 \\
\hline & 8-nonadecenoic & 19:1n-8 & 296 & 6.8 & 2.0 & nd & na \\
\hline & Gondoic & 20:1n-9 & 310 & 11.5 & 3.5 & 5.7 & 2.7 \\
\hline & Erucic & $22: 1 n-9$ & 338 & 1.3 & 0.4 & 1.8 & 0.8 \\
\hline & Nervonic & $24: 1 n-9$ & 366 & 2.6 & 0.8 & 1.4 & 0.7 \\
\hline & & Total & & 64.8 & & 33.3 & \\
\hline \multirow[t]{6}{*}{ PUFA } & Linoleic & $18: 2 n-6$ & 280 & 10.8 & 3.2 & 8.9 & 4.2 \\
\hline & Eicosadienoic & $20: 2 n-6$ & 308 & 6.2 & 1.9 & 2.7 & 1.3 \\
\hline & Dihomo- $\gamma$-linoleic & $20: 3 n-6$ & 306 & 8.6 & 2.6 & 6.7 & 3.1 \\
\hline & Arachidonic & $20: 4 n-6$ & 304 & 47.5 & 14.3 & 35.1 & 15.6 \\
\hline & Timnodonic (EPA) & $20: 5 n-3$ & 302 & 23.1 & 6.9 & 18.3 & 8.6 \\
\hline & & Total & & 96.2 & & 71.7 & 34.0 \\
\hline \multirow[t]{6}{*}{ br-FA } & Iso-pentadec. & i $15: 0$ & 228 & 1.7 & 0.5 & 1.2 & 0.6 \\
\hline & Anteiso-pentadec. & ai $15: 0$ & 228 & 1.5 & 0.5 & 1.1 & 0.5 \\
\hline & Branched-hexadec. & br 16:0 & 242 & 1.5 & 0.4 & 1.2 & 0.6 \\
\hline & Iso-heptadec. & i $17: 0$ & 256 & 2.4 & 0.7 & 1.2 & 0.6 \\
\hline & Anteiso-heptadec. & ai $17: 0$ & 256 & 2.3 & 0.7 & nd & na \\
\hline & & Total & & 9.4 & & 4.7 & \\
\hline
\end{tabular}

\section{DISCUSSION}

\section{Bulk physical and chemical composition}

Aragonite and dolomite may not be present in significant amounts in Lithothamnion corallioides in Kingstown Bay (Fig. 2). While calcite is known to be the major mineral form for the Order Corallinales, minor components of aragonite and other minerals have been shown to be present under different microclimatic conditions (Bilan \& Usov 2001, and references therein). Indeed, Blunden et al. (1977) reported that maerl is composed of $~ 80 \%$ calcite, 10 to $15 \%$ aragonite and $<8 \%$ magnesium carbonate. Thus, the apparent lack of aragonite or high magnesium carbonate may be a characteristic of maerl at this site or may be related to variations in minor carbonate polymorph abundance with microclimatic conditions. Comparison of the LM and NLM X-ray diffractogram patterns indicates that little mineralogical alteration occurs in maerl upon death and early deposition. However, because ${ }^{14} \mathrm{C}$-dating of the age differences between LM and NLM was not performed, and dating based on stratification was also not possible due to extensive tidal mixing of the maerl beds, no distinct conclusions can be drawn on the rate of mineralogical alteration at present. The IR analysis (Fig. 3) shows that overall there is a high degree of similarity in organic matter composition between LM and NLM, which indicates a minor contribution of organic matter compared to carbonate. 
Table 2. Occurrence and concentration of non-fatty acid lipids and low molecular weight carbohydrates (LMWC) in living and non-living maerl. All LMWC identified as trimethylsilyl-ether derivatives. DW: dry weight, nq: not quantified, nd: not detected, na: not applicable

\begin{tabular}{|c|c|c|c|}
\hline \multirow[t]{2}{*}{ Compound } & \multirow{2}{*}{$\begin{array}{l}\text { Molecular } \\
\text { weight } \\
\left(\mathrm{g} \mathrm{mol}^{-1}\right)\end{array}$} & \multicolumn{2}{|c|}{$\begin{array}{c}\text { Concentration } \\
\left(\mu g^{-1} \mathrm{DW}\right)\end{array}$} \\
\hline & & Living & Non-living \\
\hline \multicolumn{4}{|l|}{ Lipids } \\
\hline Tetradecanal & 212 & 3.5 & 2.0 \\
\hline Hexadecanal & 240 & 13.5 & 7.3 \\
\hline Octadecanal & 268 & 9.2 & 5.5 \\
\hline Heptadecenal & 252 & 4.7 & 1.7 \\
\hline Heptadecane & 240 & 5.3 & 3.5 \\
\hline Glycerol & 92 & 12.6 & 13.2 \\
\hline Phytol & 296 & 6.1 & 13.7 \\
\hline Phytanic acid & 312 & 7.1 & 2.1 \\
\hline Squalene & 410 & 1.8 & 1.7 \\
\hline Monopalmitin & 330 & 6.5 & 5.9 \\
\hline Monostearin & 358 & nq & nq \\
\hline Cholesterol & 386 & 22.9 & 19.2 \\
\hline$\beta$-sitosterol & 414 & 2.9 & 1.3 \\
\hline Stigmasterol & 412 & 1.0 & 1.0 \\
\hline Cholest-4-en-3-one & e 384 & 1.0 & 1.0 \\
\hline \multicolumn{4}{|l|}{ Monosaccharides } \\
\hline$\alpha$-Galactose & 180 & 26.9 & 19.8 \\
\hline$\beta$-Galactose & 180 & 15.5 & 12.8 \\
\hline$\alpha$-arabinose & 150 & 2.6 & 1.1 \\
\hline$\beta$-arabinose & 150 & 2.1 & 1.5 \\
\hline D-Xylulose & 150 & 2.1 & 0.4 \\
\hline$\alpha$-Fructose & 180 & 4.1 & 2.1 \\
\hline$\beta$-Fructose & 180 & 4.6 & 2.2 \\
\hline L-Altrose & 180 & 6.6 & 3.9 \\
\hline Total & & 64.5 & 43.8 \\
\hline \multicolumn{4}{|l|}{ Sugar alcohols } \\
\hline Xylitol & 152 & 2.3 & nd \\
\hline Arabitol & 152 & 0.8 & 0.4 \\
\hline Ribitol & 152 & 1.9 & 1.0 \\
\hline Mannitol & 182 & 6.1 & 3.8 \\
\hline Galactitol & 182 & 1.3 & 1.0 \\
\hline Total & & 12.4 & 6.2 \\
\hline Disaccharides & na & 225.5 & 192.3 \\
\hline Trisaccharides & na & 66.2 & 38.8 \\
\hline Floridoside & 254 & 39.3 & 38.0 \\
\hline Isofloridoside & 254 & 21.1 & 27.0 \\
\hline
\end{tabular}

\section{Globular inclusions}

Globular inclusions (Fig. 4) were found in SEM analysis and have been reported previously in calcified algae, but their exact identity has not been established. They have been proposed to be chloroplasts or plastids (Borowitzka et al. 1974, Ghirardelli 2002), endophytic green algae (Alexandersson 1977), endophytic bacteria (Garbary \& Veltkamp 1980) or starch grains (Wilks \& Woelkerling 1994, Blunden et al. 1997). While these structures appear to be spheroid in shape and of similar size to bacteria ( 2 to $4 \mu \mathrm{m}$ in diameter), the observed structures possess an apparent angular, rather than spheroid, morphology (Fig. 5A, ' $\mathrm{X}$ ') and are considerably larger and of different morphology than bacteria that were found in maerl samples (Fig. 5B, ' $\mathrm{Y}^{\prime}$ ). In addition, bacterial fatty acids biomarkers, such as iso- and anteisomethyl-branched alkanoic acids (e.g. Zelles 1999), were not found in high abundance in maerl, and there was little variation between LM and NLM, suggesting that extensive colonisation by endophytic bacteria of NLM is not occurring. These results suggest that these globular inclusions are not bacteria.

\section{Fatty acid and simple lipid composition}

Assessing the fatty acid composition of algae is very useful in studies related to marine organic matter cycling, ecology, chemotaxonomy (e.g. Volkman 2006) and applied research (e.g. food, biomedical and biofuels research) (Zhukova \& Aizdaicher 1995, Bigogno et al. 2002). In addition, the fatty acid composition of algae has been shown to be affected by changes in environmental conditions, such as temperature, light intensity or $\mathrm{pH}$, and can be linked to growth rate (Cohen et al. 1988). The fatty acid content was similar for LM and NLM, but there was an overall decrease in abundance in NLM (Table 1). Overall, the fatty acid composition of maerl was found to be similar to that previously reported in many marine algae, where 16:0 and 20:5n-3 (Volkman et al. 1999) are the major fatty acids. However, it is noteworthy that $20: 4 n-6$ is the major PUFA reported here, which may be a specific characteristic of Lithothamnion corallioides in Kingstown Bay. Fleurence et al. (1994) demonstrated that 20:4n-6 and 20:5n-3 were major fatty acids present in similar proportions in red macroalgae. Khotimchenko et al. (2002) showed that 20:5n-3 and 20:4n-6 were major fatty acids in all red algal species investigated, with proportions varying considerably but generally with 20:5n-3 being dominant. In contrast, the proportions of 20:4n-6 and 20:5n-3 were in similar in brown algae, and both fatty acids were present in low abundance in green algae. Graeve et al. (2002) investigated the fatty acid composition of marine arctic and antarctic macroalgae and showed that 16:0 and 20:5n-3 were the primary fatty acids and 20:4n-6 was of relatively minor abundance. However, the authors also noted that the species Phycodrys rubens and Delesseria lancifolia exhibited $20: 4 n-6$ as a major 


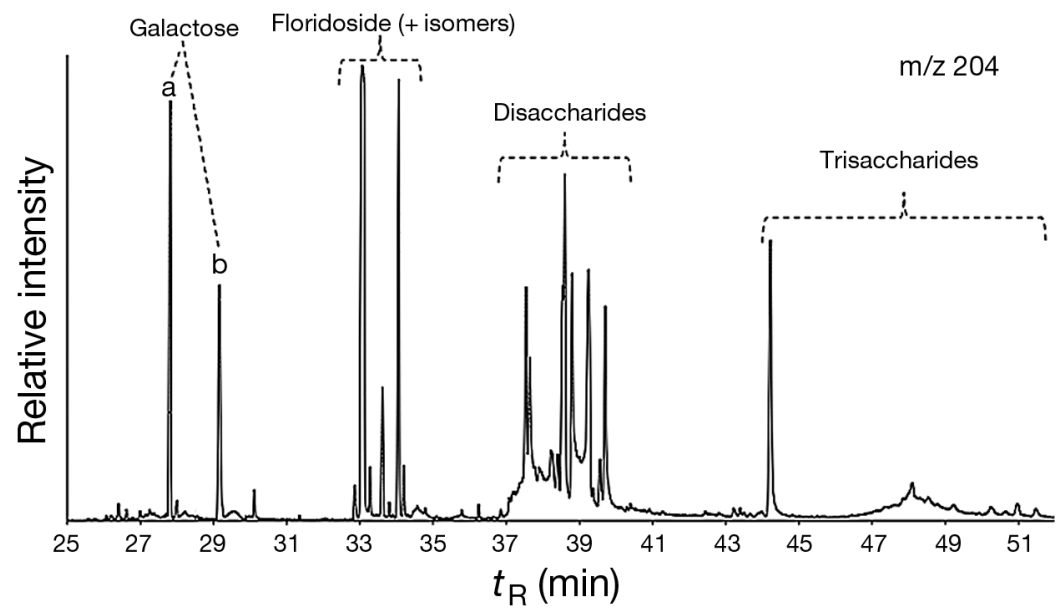

Fig. 7. Partial extracted ion chromatogram (m/z 204) of silylated extract from living maerl. $t_{\mathrm{R}}$ : retention time
1984). They can be readily identified and quantified as trimethylsilyl ethers using GC-MS (Medeiros \& Simoneit 2007, Füzfai et al. 2008). The $\alpha$ - and $\beta$ anomers of D-galactose were the major monosaccharides in LM and NLM, and complex range of disaccharides was observed, likely composed of galactose monomers (Table 2). Sulphated galactans, such as agars or carrageenans, are the most common polysaccharides extracted from red algae, are typically composed of repeating units of agarobiose or carrabiose disaccharides (Bilan \& Usov 2001, Barsanti \& Gualteri 2006) and are likely the dominant disaccharides found in maerl also.

Floridoside is commonly found in red algae and is thought to be the primary photosynthetic reserve product in most Rhodophyta (Impellizzeri et al. 1975, Raven et al. 1990, Karsten et al. 1993). Floridoside plays an important role in carbon storage, transport and assimilation and also in osmotic regulation (Weïwer et al. 2008). It is known to be a precursor in the synthesis of cell-wall polysaccharides in the red microalga Porphyridium sp. (Li et al. 2002). Variation in the abundance of floridoside and its isomers has been linked to diurnal and seasonal cycles (Karsten et al. 1993, Meng \& Srivastava 1993). Interestingly, floridoside has recently been highlighted as a potentially important new anticomplementary agent for use in therapeutic complement depletion (Courtois et al. 2008), as a potentially health-promoting prebiotic foodstuff (Ishihara et al. 2010), as an antioxidant (Li et al. 2010) and in conjunction with isethionic acid as a novel bacterial quorum-sensing inhibitor (Liu et al. 2008). Thus, in light of the recent findings highlighting Ireland's significant maerl resource (De Grave \& Whitaker 1999) and the apparent abundance of PUFA and floridoside, there is a clear potential for the commercial exploitation of maerl for biomedical, biotechnology and pharmaceutical industries. NLM has been shown to possess similar concentrations of floridoside (and PUFA) and may therefore be a more appropriate option for commercial exploitation.

\section{LMWC composition and occurrence of floridoside in maerl}

Carbohydrates are common structural and storage compounds in terrestrial and marine organisms and are the primary form of photosynthetically assimilated carbon in the atmosphere (Cowie \& Hedges
Acknowledgements. We thank the Geological Survey of Ireland, the Irish Research Council for Science, Engineering \& Technology (IRCSET), INFOMAR (Integrated Mapping for the Sustainable Development of Ireland's Marine Resources), the Irish Environmental Protection Agency, the Science Foundation of Ireland and QUESTOR for funding 
this research. We also thank B. Twamley (Dublin City University) for SEM training and B. O' Connor (AQUAFACT Services) for benthic sampling and advice. We thank 3 anonymous reviewers for their helpful comments.

\section{LITERATURE CITED}

Alexandersson T (1977) Carbonate cementation in recent coralline algal constructions. In: Flugel E (ed) Fossil algae. Springer, Berlin, p 261-269

Barbera C, Bordehore C, Borg JA, Glémarec J and others (2003) Conservation and management of northeast Atlantic and Mediterranean maerl beds. Aquatic Conserv 13:S65-S76

Barsanti L, Gualteri P (2006) Algae: anatomy, biochemistry and biotechnology. CRC Taylor \& Francis, Boca Raton, FL

Bigogno C, Khozin-Goldberg I, Boussiba S, Vonshk A, Cohen Z (2002) Lipid and fatty acid composition of the green oleaginous alga Parietochloris incisa, the richest plant source of arachidonic acid. Phytochemistry 60: 497-503

Bilan MI, Usov AI (2001) Polysaccharides of calcareous algae and their effect on the calcification process. Russ J Bioorg Chem 27:2-16

BIOMAERL Team (1999) Maerl biodiversity: functional structure and anthropogenic impacts. Final report contract MAS 3-CT95-0020. University Marine Biological Station, Millport, Scotland

Blake C, Maggs CA (2003) Comparative growth rates and internal banding periodicity of maerl species (Corallinales, Rhodophyta) from northern Europe. Phycologia 42:606-612

Blunden G, Binns WW, Perks F (1975) Commercial collection and utilization of maerl. Econ Bot 29:141-145

Blunden G, Farnham WF, Jephson N, Fenn RH, Plunkett BA (1977) The composition of maerl from the Glenan Islands of southern Brittany. Bot Mar 20:121-125

- Blunden G, Campbell SA, Smith JR, Guiry MD, Hession CC, Griffin RL (1997) Chemical and physical characterization of calcified red algal deposits known as maerl. J Appl Phycol 9:11-17

Bordehore C, Ramos-Esplá AA, Riosmena-Rodríguez R (2003) Comparative study of two maerl beds with different otter trawling history, southeast Iberian Peninsula. Aquatic Conserv 13:S43-S54

Borowitzka MA, Larkum AWD, Nockolds NE (1974) A scanning electron microscope study of the structure and organization of the calcium carbonate deposits of algae. Phycologia 13:195-203

Bosence D (1983) Coralline algal reef frameworks. J Geol Soc London 140:365-376

Bosence D, Wilson J (2003) Maerl growth, carbonate production rates and accumulation rates in the northeastern Atlantic. Aquatic Conserv 13:S21-S31

Brokł M, Soria AC, Martinez-Castro I, Sanz ML, RuizMatute AI (2009) Characterization of O-trimethylsilyl oximes of trisaccharides by gas chromatography-mass spectrometry. J Chromatogr A 1216:4689-4692

Cohen Z, Vonshak A, Richmond A (1988) Effect of environmental conditions on fatty acid composition of the red algae Porphyridium cruentum: correlation to growth rate. J Phycol 24:328-332

Courtois A, Simon-Colin C, Boisset C, Berthou C, Deslandes
E, Guézennec J, Bordron A (2008) Floridoside extracted from the red alga Mastocarpus stellatus is a potent activator of the classical complement pathway. Mar Drugs 6: 407-417

> Cowie GL, Hedges JI (1984) Carbohydrate sources in coastal marine environments. Geochim Cosmochim Acta 48: 2075-2087

De Grave S, Whitaker A (1998) Benthic community readjustment following dredging of a muddy-maerl matrix. Mar Pollut Bull 38:102-108

De Grave S, Whitaker A (1999) A census of maerl beds in Irish waters. Aquat Conserv 9:303-311

> De Rosa S, De Giulio A, Iodice C, Alcarez MJ, Paya M (1995) Long chain aldehydes from the red algae, Corallina mediterranea. Phytochemistry 40:995-996

Downs RT, Hall-Wallace M (2003) The American mineralogist crystal structure database. Am Mineral 88:247-250

European Council (1992) Directive 92/43/EEC: On the conservation of natural habitats and of wild fauna and flora. Official Journal of the European Union L 206, p 7-50

Fang J, Chan O, Joeckel RM, Huang Y and others (2006) Biomarker analysis of microbial diversity in sediments of a saline groundwater seep of Salt Basin, Nebraska. Org Geochem 37:912-931

Fleurence J, Gutbier G, Mabeau S, Leray C (1994) Fatty acids from 11 marine macroalgae of the French Brittany coast. J Appl Phycol 6:527-532

> Foster MS (2001) Rhodoliths: between rocks and soft places. J Phycol 37:659-667

> Freiwald A, Henrich R (1994) Reefal coralline algal buildups within the Arctic Circle: morphology and sedimentary dynamics under extreme environmental seasonality. Sedimentology 41:963-984

Füzfai Z, Boldizar I, Molnar-Perl I (2008) Characteristic fragmentation patterns of trimethylsilyl and trimethylsilyl oxime derivatives of various saccharides as obtained by gas chromatography coupled to ion-trap mass spectrometry. J Chromatogr A 1177:183-189

Garbary D, Veltkamp CJ (1980) Observations on Mesophyllum lichenoides (Corallinaceae, Rhodophyta) with the scanning electron microscope. Phycologia 19:49-53

Ghirardelli LA (2002) Endolithic microorganisms in live and dead thalli of coralline red algae (Corallinales, Rhodophyta) in the Northern Adriatic Sea. Acta Geol Hisp 37:53-60

> Graeve M, Kattner G, Wiencke C, Karsten U (2002) Fatty acid composition of Arctic and Antarctic macroalgae: indicator of phylogenetic and trophic relationships. Mar Ecol Prog Ser 231:67-74

> Grall J, Hall-Spencer JM (2003) Problems facing maerl conservation in Brittany. Aquat Conserv 13:S55-S64

Impellizzeri G, Mangiafico S, Oriente G, Piatelli M, Sciuto S (1975) Amino acids and low-molecular-weight carbohydrates of some marine red algae. Phytochemistry 14: 1549-1557

> Ishihara K, Oyamada C, Sato Y, Suzuki T, Kaneniwa M, Kunitake H, Muraoka T (2010) Prebiotic effect of glycerol galactoside isolated from color-faded nori in rats. Fish Sci 76:1015-1021

> Kajiwara T, Matsui K, Hatanaka A, Tomoi T, Fujimura T, Kawai $T$ (1993) Distribution of an enzyme system producing seaweed flavor: conversion of fatty acids to longchain aldehydes in seaweeds. J Appl Phycol 5:225-230

Kamenos NA, Cusack M, Moore PG (2008) Coralline algae are global paleothermometers with bi-weekly resolution. 
Geochim Cosmochim Acta 72:771-779

Karsten U, Barrow KD, King RJ (1993) Floridoside, L-isofloridoside, and D-isofloridoside in the red alga Porphyra columbina (seasonal and osmotic effects). Plant Physiol 103:485-491

Khotimchenko SV, Vaskovsky VE, Titlyanova TV (2002) Fatty acids of marine algae from the Pacific coast of North California. Bot Mar 45:17-22

Li SY, Shabtai Y, Arad SM (2002) Floridoside as a carbon precursor for the synthesis of cell-wall polysaccharide in the red microalga Porphyridium sp. (Rhodophyta). J Phycol 38:931-938

Li YX, Li Y, Lee SH, Qian ZJ, Kim SJ (2010) Inhibitors of oxidation and matrix metalloproteinases, floridoside, and D-isofloridoside from marine red alga Laurencia undulata. J Agric Food Chem 58:578-586

Liu HB, Kyong PK, Kim JS, Seo Y, Park S (2008) The effects of betonicine, floridoside, and isethionic acid from the red alga Ahnfeltiopsis flabelliformis on quorum-sensing activity. Biotechnol Bioproc Eng 13:458-463

Medeiros PM, Simoneit BRT (2007) Analysis of sugars in environmental samples by gas chromatography-mass spectrometry. J Chromatogr A 1141:271-278

Meng J, Srivastava LM (1993) Variations in floridoside content and floridoside phosphate synthase activity in Porphyra perforata (Rhodophyta). J Phycol 29:82-84

Nichols PD, Guckert JB, White DC (1986) Determination of monounsaturated fatty acid double bond position and geometry for microbial monocultures and complex consortia by capillary GC-MS of their dimethyl disulphide adducts. J Microbiol Methods 5:49-55

Raven JA, Johnston AM, MacFarlane JJ (1990) Carbon metabolism. In: Cole KM, Sheath RG (eds) Biology of the red algae. Cambridge University Press, Cambridge, p 172-202

Editorial responsibility: Christine Paetzold, Oldendorf/Luhe, Germany
Sánchez-Machado DI, López-Cervantes J, López-Hernández J, Paseiro-Losado P (2004) Fatty acids, total lipid, protein and ash contents of processed edible seaweeds. Food Chem 85:439-444

- Titschack J, Nelson CS, Beck M, Freiwald A, Radtke U (2008) Sedimentary evolution of a Late Pleistocene temperate red algal reef (Coralligène) on Rhodes, Greece: correlation with global sea-level fluctuations. Sedimentology 55:1747-1776

> van Ginneken VJT, Helsper JPFG, de Visser W, van Keulen H, Brandenburg WA (2011) Polyunsaturated fatty acids in various macroalgal species from north Atlantic and tropical seas. Lipids Health Dis 10:104

Volkman JK (2006) Lipid biomarkers in marine organic matter. In: Volkman JK (ed) Handbook of Environmental Chemistry, Vol 2, Part N. Springer, Berlin, p 27-70

> Volkman JK, Barrett SM, Blackburn SI (1999) Fatty acids and hydroxy fatty acids in three species of freshwater eustigmatophytes. J Phycol 35:1005-1012

> Weïwer M, Sherwood T, Linhardt RJ (2008) Synthesis of floridoside. J Carbohydr Chem 27:420-427

> Wilks KM, Woelkerling LJ (1994) An account of the southern Australian species of Phymatolithon (Corallinaceae, Rhodophyta) with comments on Leptophytum. Aust Syst Bot 7:183-223

Wilson S, Blake C, Berges JA, Maggs CA (2004) Environmental tolerances of free-living coralline algae (maerl): implications for European marine conservation. Biol Conserv 120:279-289

Zelles L (1999) Fatty acid patterns of phospholipids and lipopolysaccharides in the characterization of microbial communities in soil: a review. Biol Fertil Soils 29:111-129

- Zhukova NV, Aizdaicher NA (1995) Fatty acid composition of 15 species of marine microalgae. Phytochemistry 39: 351-356

Submitted: July 21, 2011; Accepted: March 16, 2012 Proofs received from author(s): May 17, 2012 